\title{
Prospects of Fly Ash Application in Agriculture: A Global Review
}

\author{
Harender Singh Dahiya* and Yogendra Kumar Budania
}

State Agriculture Department, Government of Haryana, India

*Corresponding author

\begin{tabular}{|l|}
\hline Key w or d s \\
Non-renewable \\
resources, Coal, \\
Ash application
\end{tabular}

\section{Introduction}

India has one of the largest reserves of coal in the world. Out of many byproducts of coal combustion, fly ash is one of the major by product which can be utilized potentially in agriculture. Fly ash is an amorphous mixture of ferroaluminosilicate minerals generated from combustion of coal at a temperature of 400-1500 ${ }^{0} \mathrm{C}$. Fly ash is composed predominantly of small, glassy, hollow particles with low to medium bulk density ranging from 2.1 to $2.6 \mathrm{~g} \mathrm{~cm}^{-3}$ (Adriano et al., 1980) with an average diameter of $<10 \mu \mathrm{m}$, high surface area and light texture which are aggregated into micron and sub-micron spherical particles of sizes ranging from 0.01 to $100 \mathrm{~mm}$ (Davison et al., 1974), with smaller particles entrapped within large spheres (Fischer et al., 1976). At present scenario, around 200 million-tons of fly-ash is produced which is nearly twice over the last 
decade and the quality of ash varies from plant to plant and from coke to coke depending on source of supply and type combustion. In India about $80 \%$ power is produced by pulverized coal fired boilers (Fly AshWikipedia, 2011) and thermal power plants are utilizing bituminous and sub-bituminous high ash containing (30-50\%) coal, in addition to several captive power plants, contributes to indiscriminate disposal of this industrial waste every year (Jamwal, 2003; Garg et al., 2005). In India, flyash utilization has increased from $3 \%$ in the 1990s [5] to $38 \%$ in 2005 [3].

The reason of low fly-ash utilization in India is the unavailability of appropriate costeffective technologies. Many research experiments and studies all around the world is going on to study the effect and potential of fly-ash as an amendment in agricultural or other applications by various agencies, research institutes. Here in this paper we focused on utilization of fly-ash as a valueadded product of agriculture and reducing the environmental and economic impacts of disposal.

\section{Types of fly ash}

The quality of coal depends upon its rank and grade. The coal rank arranged in an ascending order of carbon contents is: Peat $<<$ Lignite $<$ sub-bituminous coal $<$ bituminous coal $<<$ anthracite.

Indian coal is of mostly sub bituminous rank followed by bituminous and lignite (brown coal). The ash content in Indian coal ranges from $35 \%$ to $50 \%$ and the methods of fly ash transfer i.e. dry, wet and/or both are presented in figure 1 .

There are generally three categories of coal ashes available from thermal power stations and are mentioned below:

\section{Dry fly ash}

Collected from different rows of electrostatic precipitator in dry form.

The fly ash produced from the burning of pulverized coal in a coal-fired boiler is a fine grained,

Powdery particulate material that is carried off in the flue gas and usually collected from the flue gas by means of electrostatic precipitators, bag-houses, or mechanical collection devices such as cyclones.

\section{Bottom ash}

Collected at the bottom of the boiler furnace and is characterized by better geotechnical properties.

\section{Pond ash}

Fly ash and bottom ashes are mixed together with water to form slurry which is pumped to the ash pond area. In the ash pond the, ash gets settled and excess water is decanted. This deposited ash is pond ash.

\section{Characterization of fly ash}

According to IS 3812-1981, there are two grades of Fly Ash

Grade I fly ash, which are derived from bituminous coal having fractions $\mathrm{SiO}_{2}+\mathrm{Al}_{2} \mathrm{O}_{3}+\mathrm{Fe}_{2} \mathrm{O}_{3}$ greater than $70 \%$.

Grade II Fly ash, which are derived from lignite coal having fractions $\mathrm{SiO}_{2}+\mathrm{Al}_{2} \mathrm{O}_{3}+\mathrm{Fe}_{2} \mathrm{O}_{3}$ greater than $50 \%$.

ASTM C618 specified two categories of fly ash, Class $\mathrm{C}$ and Class $\mathrm{F}$ depending on the type of coal and the resultant chemical analysis. 


\section{Class F fly ash}

The burning of harder, older anthracite and bituminous coal typically produces Class F fly ash. This fly ash is pozzolanic in nature, and contains less than $7 \%$ lime $(\mathrm{CaO})$. Possessing pozzolanic properties, the glassy silica and alumina of Class $\mathrm{F}$ fly ash requires a cementing agent, such as Portland cement, quicklime, or hydrated lime-mixed with water to react and produce cementitious compounds. Alternatively, adding a chemical activator such as sodium silicate (water glass) to a Class $\mathrm{F}$ ash can form a geopolymer.

\section{Class C fly ash}

Fly ash produced from the burning of younger lignite or sub-bituminous coal, in addition to having pozzolanic properties, also has some self-cementing properties. In the presence of water, Class $\mathrm{C}$ fly ash hardens and gets stronger over time. Class $\mathrm{C}$ fly ash generally contains more than $20 \%$ lime $(\mathrm{CaO})$. Unlike Class F, self-cementing Class $\mathrm{C}$ fly ash does not require an activator. Alkali and sulfate $\left(\mathrm{SO}_{4}\right)$ contents are generally higher in Class $\mathrm{C}$ fly ashes.

\section{Properties of flyash}

Physical, chemical and other properties of fly ash play an important role in imparting it the pozzolanic reactivity and in its interaction with cement mortar and concrete. Ninety-five percent of the inorganic matter contained in coal is made up of clay or shale, pyrite and calcite minerals. Lignite coals contain the most calcite and bituminous the least. Subbituminous coals fall in between. The alkalies and trace minerals account for the rest of the minerals. Fly ash is an amorphous mixture of ferroaluminosilicate minerals generated from the combustion of ground or powdered coal at 400-1500 ${ }^{\circ} \mathrm{C}$ (Mattigod et al., 1990). Physically, fly ash occurs as very fine particles having an average diameter of $<10 \mu \mathrm{m}$ and has low to medium bulk density, high surface area and light texture. Fly ash material solidifies while suspended in the exhaust gases and is collected by electrostatic precipitators or filter bags. Since the particles solidify rapidly while suspended in the exhaust gases, fly ash particles are generally spherical in shape and range in size from $0.5 \mu \mathrm{m}$ to $300 \mu \mathrm{m}$. Most of the fly ash particles are glassy or amorphous. Yet, quartz, mullite, magnetite and calcium compounds including calcium sulfate may be present as crystalline compounds constituting about 15 per cent by weight of the fly ash.

\section{Some of the important properties of fly ash are discussed below}

Fineness of fly ash is most closely related to the operating condition of the coal crushers and the grindability of the coal itself. For fly ash use in concrete applications, fineness is defined as the percent by weight of the material retained on the $0.044 \mathrm{~mm}$ (No. 325) sieve. A coarser gradation can result in a less reactive ash and could contain higher carbon contents. Limits on fineness are addressed by ASTM and state transportation department specifications. Fly ash can be processed by screening or air classification to improve its fineness and reactivity (Anonymous, 2003). Fly ash particles of very small size are mostly made up of clear glass spheres. Spongy particles formed either by fusion of many fine particles or from ore minerallic particles are also common in most fly ashes. The particles in bituminous ash range from less than $1 \mathrm{pm}$ to over $100 \mathrm{pm}$ but average particle size in such ashes may vary from $7 \mathrm{pm}$ to $12 \mathrm{pm}$. The majorities of particles are finer than the average size and contribute to the high specific surface area as determined by Blaine air permeability method or by single point B.E.T. nitrogen sorption method. The surface area of the fly ash particles has been reported to vary from about $2000 \mathrm{~cm} * / \mathrm{g}$ to over 10,000 
$\mathrm{cm}^{*} / \mathrm{g}$ depending on the proportion of fine particles in the fly ash. The values of specific surface area are reported to range from 1800 to $5900 \mathrm{~cm} * / \mathrm{g}$. Murugan and Murugaiyan (2013) reported that fly ash is generally of silt loam texture with the particles diameter of less than $0.010 \mathrm{~mm}$ and had fly ashes have the $\mathrm{pH}$ value of 6-11, electrical conductivity (EC) 42$450 \mu \mathrm{S} / \mathrm{cm}$. Most of the fly ash has the bulk density (BD) values less than $1 \mathrm{~g} / \mathrm{cm} 3$ and water holding capacity $43-66 \%$ while Mishra and Shukla (1986) observed that the major portion of fly ash $(60 \%)$ consisted of silt sized fraction (0.02 to $0.002 \mathrm{~mm})$, whereas sand size particles (2 to $0.02 \mathrm{~mm}$ ) represented $25 \%$ and clay size particles (below $0.002 \mathrm{~mm}$ ) $10 \%$ of the fly ash weight. The bulk density of fly ash was $1.02 \mathrm{~g} \mathrm{~cm}^{-3}$. Fly ash can be tan to dark gray, depending on its chemical and mineral constituents. Tan and light colors are typically associated with high lime content. A brownish color is typically associated with the iron content. A dark gray to black color is typically attributed to elevated unburned carbon content (Pandey and Singh, 2010). Fly ash color is usually very consistent for each power plant and coal source. Specific gravity is one of the important physical properties needed for the use of coal ashes for geotechnical and other applications. In general, the specific gravity of coal ashes varies around 2.0 but can vary to a large extent (1.6 to 3.1). Specific gravity is frequently required for finding out the degree of saturation, void ratio, unit weight of soil solids or moist soils. The unit weights "in turn are needed in pressure, settlement and stability problems in soil or geotechnical engineering. Therefore specific gravity is a very important physical-property of fly ash as a geo-material. In general, fly ash is characterised by low specific gravity. One explanation for this lower specific gravity is the feet that a high proportion of fly ash particles are cenospheres or hollow particles (Nyambura et al., 2011). The specific gravity of minerallic fly ash particles is found to vary from less than 1 for hollow spherical particles called cenospheres to about 4.8 for spherical and rounded light brown to black particles that contain 50 to 95 percent of the total iron present in fly ash. Irregularly shaped black particles of unburned coal have a specific gravity of about 1.3. Specific gravity of fly ash depends on carbon and iron oxides contents. He found that a small increase in carbon content of a fly ash results in a significant drop in specific gravity (Adriano et al., 1980). Variation of specific gravity of coal ash is due to the combination of many factors such as gradation, particle shape and chemical composition, ashes with high iron contents have high specific gravity values (Pandian et al., 1998). Thus, specific gravity of fly ash particles varies significantly depending upon the proportion of cenospheres, iron rich magnetite and unburned carbon particles. Grain size distribution indicates if a material is well graded, poorly graded, fine or coarse, etc. and also helps in classifying the coal ashes. Coal ashes are predominantly silt sized with some sand-size fraction.

Chemical composition suggests the possible applications for coal ash. The investigations carried out on Indian fly ashes show that all the fly ashes contain silica, alumina, iron oxide and calcium oxide. The silica content in fly ashes is between 38 and 63\%, 37 and $75 \%$ in pond ashes, and 27 and $73 \%$ in bottom ashes. The alumina content ranged between 27 and $44 \%$ for fly ashes, 11 and 53\% for pond ashes and 13 and $27 \%$ for bottom ashes. The calcium oxide is in the range of 0 to $8 \%$ for fly ashes, 0.2 to $0.6 \%$ for pond ashes and 0 to $0.8 \%$ for bottom ashes (Plank and Martens, 1974). There are mainly two types of ash, i.e: Class F (low lime) and Class C (high lime) based on total amounts of silica, alumina and iron oxide. Al in fly ash is mostly bound in insoluble aluminosilicate structures, which considerably limits its biological toxicity (Page et al., 1979). It is substantially rich in 
trace elements like lanthanum, terbium, mercury, cobalt and chromium (Adriano et al., 1980). Many trace elements in fly ash like As, $\mathrm{B}, \mathrm{Ca}, \mathrm{Mo}, \mathrm{S}, \mathrm{Se}$ and $\mathrm{Sr}$ are concentrated in the smaller ash particles (Page et al., 1979). The authors opined that oxidation of $\mathrm{C}$ and $\mathrm{N}$ during combustion drastically reduces their quantities in ash. The $\mathrm{pH}$ of fly ash varies from 4.5-12.0 depending largely on the sulphur content of the parent coal and the type of coal used for combustion affects the sulphur content of fly ash (Page et al., 1979). The solubility of fly ash depends directly on the physicochemical disintegration of the particles, for example indicating that a major portion of total $\mathrm{K}$ is localized in the interior glassy matrix while the external glass is enriched with $\mathrm{Mg}$. When the solubility of alkaline fly ash was studied by selective dissolution in mineral acids, it was found that significant quantity of $\mathrm{K}$ occurred in the highly refractory magnetic $\mathrm{Fe}$ fraction and that the solubility of $\mathrm{Mg}$ in acids was much higher (Green and Manahan, 1978).

\section{Fly ash and Agriculture}

\section{Effect of fly ash on physico-chemical properties of soil}

Fly ash has immense potential as a soilameliorating agent in agriculture, forestry and wasteland reclamation because of its heterogenous nature. Previous work (Reynolds et al., 1999) to determine the feasibility of converting waste disposal problem into a soil benefaction strategy has proven true. Fly ash has been studied as a useful soil-amending agent with agronomic and environmental benefits (Zhang et al., 2004). Studies have been carried out to report the efficacy of fluidized bed combustion (FBC) and flue gas desulfurization (FGD) byproducts, when amended with dairy, swine and broiler litter manures, in reducing phosphorus $(\mathrm{P})$ solubility and potential impact on water quality (Zhang et al., 2004). A number of studies have shown that addition of alkaline ash can increase the pH of acidic soils (Plank et al., 1975). Fly ash has been observed to have a positive effect on water holding capacity, hydraulic conductivity and $\mathrm{pH}$ apart from acting as source of nutrients and addition of unweathered fly ash up to $8 \%$ to calcareous or acidic soils resulted in higher crop yield due to increased availability of $\mathrm{S}$ from fly ash (Page et al., 1979). Fly ash applied on acidic strip mine spoils at different places increased the yield of many crops which was attributed to increased availability of $\mathrm{Al}^{3+}$ and $\mathrm{Mn}^{2+}$ and other metallic ions at the resultant higher $\mathrm{pH}$ (Fail and Wochok, 1977). West and McBride (2005) observed that the available water capacity of the sand was increased by the addition of 30 per cent fly ash. They also found that although 100 per cent ash had the greatest available water holding capacity, yields on these treatments were not the highest because of limited aeration and the change in water content from $10 \mathrm{Kpa}$ to near saturation.

Craini (1988) observed no significant effect on mechanical composition of soil, mean weight diameter, water holding capacity, $\mathrm{pH}, \mathrm{EC}$, $\mathrm{CEC}$ and available nutrients $(\mathrm{N}, \mathrm{P}, \mathrm{K}, \mathrm{Ca}, \mathrm{Mg}$, $\mathrm{S}, \mathrm{Zn}, \mathrm{Fe}, \mathrm{Mn}, \mathrm{Cu}$ and $\mathrm{B}$ ) but addition of fly ash to clay soils significantly reduced the bulk density of a clay soil and resulted in increased porosity and void ratio. Fly ash addition significantly reduced water holding capacity, bulk density, organic carbon, free $\mathrm{CaCO}_{3}$, CEC and increased the content of sand which improved the soil texture (Kene et al., 1991) while Maiti et al., (1990) found that application of fly ash to light textured soil improved the soil texture, thereby increased their water holding capacity. Matte et al., (1996) concluded from their study that fly ash alone or in combination with recommended dose of fertilizer had significant effect on water holding capacity and bulk density. Addition of $10 \%$ of fly ash increased the 
available water capacity by 7.2 for the fine and 13.5 for coarse sand, respectively. Gourab and Joy (2011) reported that $\mathrm{pH}, \mathrm{EC}, \mathrm{PO}_{4}, \mathrm{Ca}$ and $\mathrm{Na}$ of soil increased with fly ash dose and time, but $\mathrm{OC}, \mathrm{NO}_{3}$ and $\mathrm{K}$ decreased with increasing doses of fly ash. Application of fly ash significantly altered physic-chemical properties of soil which includes soil texture, decrease bulk density, increase water holding capacity, soil porosity, $\mathrm{pH}$, electrical conductivity and organic carbon values of the soil.

A marginal increase was also observed in the concentration of $\mathrm{P}, \mathrm{K}, \mathrm{S}, \mathrm{Fe}, \mathrm{Zn}, \mathrm{Mn}, \mathrm{B}, \mathrm{Ca}$ and $\mathrm{Mg}$ elements in the fly ash amended soil (Khajanchi et al., 2012). Singh et al., (2011) studied that effect of different doses of fly ash and FYM on the nitrogen dynamics and paddy productivity. Fly ash and FYM treated plots had significantly higher organic carbon content, total $\mathrm{N}$, total $\mathrm{P}$, water holding capacity but lower bulk density as compared to control and positive relationship exist between gravimetric soil moisture content an $\mathrm{N}$-mineralization and infiltration rate.

Reddy et al., (2010) studied the effect of varying level of fly ash and FYM on physicochemical properties and yield of rice grown on Inceptisol. Application of fly ash @ $15 \mathrm{t} \mathrm{ha}^{-1}+$ FYM $10 \mathrm{t} \mathrm{ha}^{-1}$ recorded the highest available $\mathrm{N}, \mathrm{P}, \mathrm{K}, \mathrm{S}, \mathrm{Fe}$ and $\mathrm{Zn}$ content of soil. The available $\mathrm{Mn}$ content was highest in FA10 FYM10 (6.69 $\mathrm{mg} \mathrm{kg}^{-1}$ ) and available $\mathrm{Cu}$ content was not influenced by fly ash levels; however, it was significantly higher in FYM treated plots. Saini et al., (2010) reported impact of fly ash and FYM incorporation in soil on yield and nutrient availability to rice. The effect of fly ash on concentration of macro and micronutrients in rice showed considerable increase when grown in fly ash incorporated soil with and without FYM application. The uptake of macro and micronutrient by rice grain also increased correspondingly with increasing level of fly ash application.

Shenggao and Lei (2004) studied that effect of fly ash on physical properties of Ultisols. Fly ash was mixed in two acid clay loams (typic plithudult and typic hapludults) at the rates of $0,5,10,20,30$ and $50 \%$ by weight on application of $50 \%$ fly ash, there was significant increase in percentage of silt particles and decrease in clay content. Effect of fly ash (30 and 50\%) to another soil caused a significant change in micro aggregate size disruption of soil, while non-significant differences were observed in the rates of 5, 10 and $20 \%$ fly ash. Fly ash application not only increased water content but also increased plant available water. Sharma et al., (2002) evaluated fly ash addition effect on soil environment and yield of wheat crop. Fly ash application levels were up to 50t/ha. Application of fly ash@10 t/ha in soil showed reduced hydraulic conductivity and improved moisture retention at field capacity and permanent wilting point. The $\mathrm{pH}$ value of soil decreased, whereas electrical conductivity, organic carbon and sodium increased in accordance with fly ash addition in soil. Deshmukh et al., (2000) reported that increasing addition of fly ash decreased bulk density and maximum water holding capacity of soil, while no marked effects on $\mathrm{pH}, \mathrm{EC}$, cation exchange capacity and lime content was observed. The available NPK and $\mathrm{Cu}, \mathrm{Fe}, \mathrm{Zn}$, and $\mathrm{Mn}$ and exchangeable $\mathrm{Ca}$ and $\mathrm{Mg}$ increased with fly ash application.

Incorporation of 'slash' in soil had positive effect on soil $\mathrm{pH}$ and $\mathrm{Ca}, \mathrm{Mg}$ and $\mathrm{P}$ content and reduction in the translocation of $\mathrm{Ni}$ and Cd (Rethman et al., 2001) and enhanced growth of corn, potatoes and beans in pot trials. The mine spoils could be revegetated by enhancing the activities of various enzymes such as dehydrogenase, phosphatase and nitrogenase upon inoculation with arbuscular 
mycorrhizal fungi Glomus mosseae (Rao and Tak, 2001). Very little is known regarding the effect of fly ash amendment on soil biological properties (Schutter and Fuhrmann, 2001). Fly ash was mixed with organic matter in the form of cow dung at 1:3,1:1 and 3:1 ratio and incubated with and without epigeic earthworm (Eisenia fetida) for 50 days which resulted in a significant increase in the population of phosphate-solubilizing bacteria and increased bioavailability of phosphorus and nutrients by vermicomposting (Bhattacharya and Chattopadhyay, 2002). Application of fly ash at $40 \mathrm{t} /$ ha in conjunction with phosphate solubilizer, Pseudomonas striata improved the bean yield and phosphorus uptake by grain and fly ash did not exert any detrimental effect on the population of $P$. striata in soil (Gaind and Gaur, 2002). Amendment of Class F bituminous fly ash to soil at a rate of 505 $\mathrm{Mg} / \mathrm{ha}$ did not show any detrimental effect on soil microbial communities. Analysis of community fatty acids indicated elevated populations of fungi, including arbuscular mycorrhizal fungi and Gram-negative bacteria (Schutter and Fuhrmann, 2001). Thus a clear cut beneficial effect of fly ash application on improvement of soil health in respect of physico-chemical parameters was observed from above cited references.

Fig.1 Methods of fly ash transfer- dry, wet and/or both

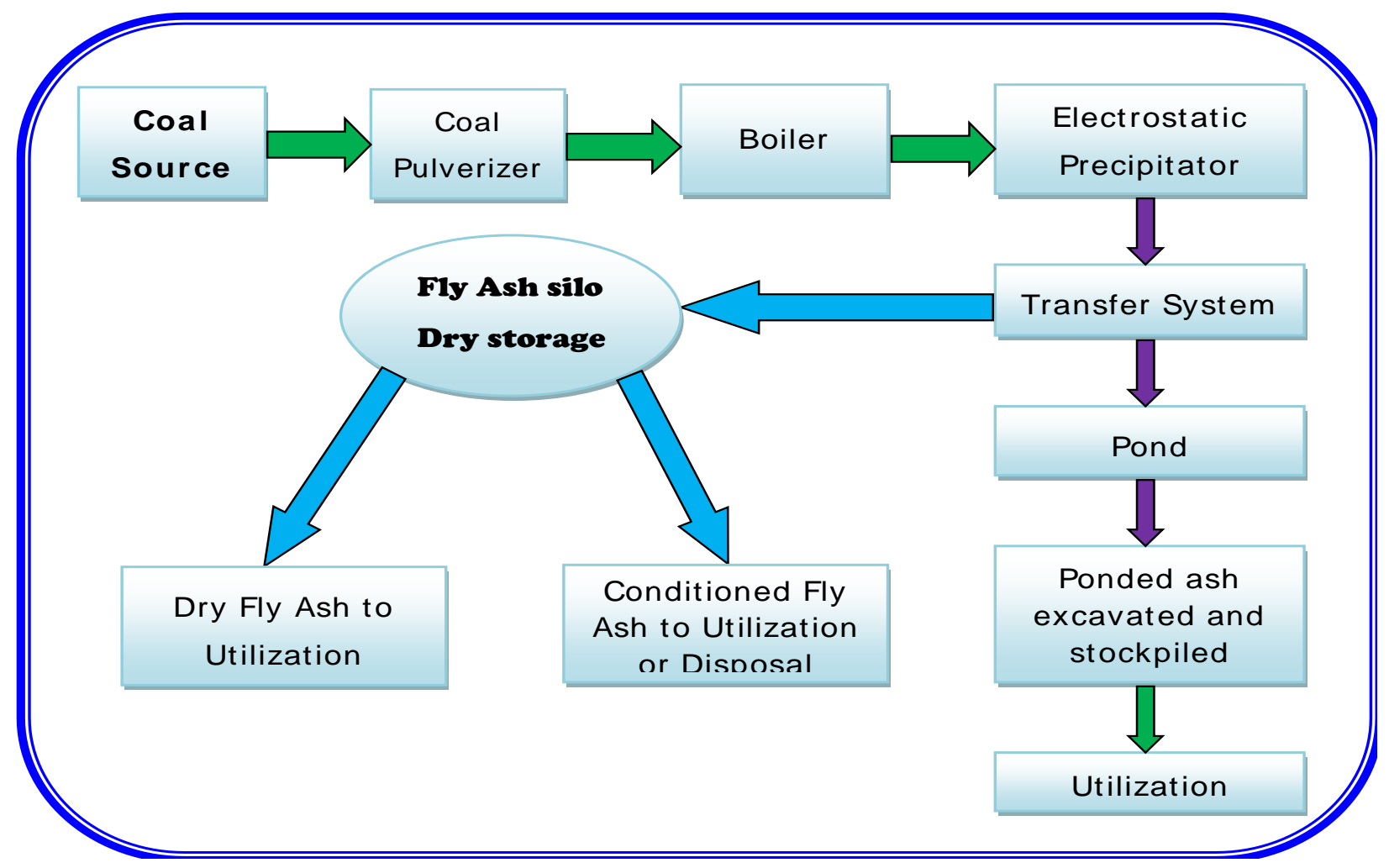

Effect of fly ash on production of agricultural crops

Agricultural utilization of fly ash has been proposed because of its considerable content of $\mathrm{K}, \mathrm{Ca}, \mathrm{Mg}, \mathrm{S}$ and $\mathrm{P}$ (Singh et al., 1997).
Fly ash is the inorganic solid component of the residue from the combustion of fuels and can be used in agriculture as a soil amendment or fertilizer and its addition generally results in consistently favourable impact on plant growth and nutrient uptake 
(Aitken et al., 1984). Adriano et al., (1978) observed that application of 5, 10, 15 and 20 per cent fly ash by weight resulted in $\mathrm{P}$ deficiency symptoms in corn, while symptoms characteristic of ' $\mathrm{B}$ ' toxicity occurred in beans. Analysis of tissues of both crops indicated that ' $\mathrm{P}$ ' concentrations were at deficient levels, while $\mathrm{Cu}, \mathrm{Mn}$ and $\mathrm{Zn}$ were deficient to marginal, Fe however, appeared to be in the normal range.

Furr et al., (1979) observed that selenium concentration in the plant tissues consistently increased with fly ash treatment. This increase was shown to be roughly proportional to either rates of fly ash application or selenium content of fly ash. Application of 20 per cent fly ash significantly increased the content of $\mathrm{N}, \mathrm{P}, \mathrm{K}$ at all the growth stages of rice plant. Uptake of these nutrients by grain and straw also increased in plants grown with 20 per cent fly ash treatment. On the other hand application of fly ash at 30 per cent level decreased the content and uptake of these nutrients (Singh and Singh, 1986). Hussain (1993) observed that the uptake of N, P and K by groundnut crop increased significantly due to application of amendment of fly ash at different levels. Similar trends in the uptake of $\mathrm{Zn}, \mathrm{Fe}$ and $\mathrm{Mn}$ by groundnut crop were observed. The increased uptake of nutrients by the crop was mainly due to increase in the availability of these nutrient elements in soil consequent to the application of amendments and fly ash levels. Mattee and Thakare (1994) recorded higher $\mathrm{N}$ and $\mathrm{P}$ uptake in groundnut where fly ash was applied @ 10 t/ha. Selvakumari et al., (2000) conducted field experiment to study the effect of integration of fly ash with fertilizer and organic manures on yield and nutrient uptake of rice in Alfisols. The highest yield (69.00 q/ha) was recorded when fly ash applied was @ 40 t/ha in combination with fertilizer, compost and Azospirillum. Moreover, Rungsun et al., (2004) also concluded that the application of coal ash mixture, either fly ash or clinker ash at $18.75-25 \mathrm{t} / \mathrm{ha}$ was the most effective in terms of plant yield. The use of coal ash mixture increased cation exchange capacity, base saturation percentage and $\mathrm{Ca}, \mathrm{Mg}$ and $\mathrm{S}$ contents in the soil as well as plant uptake of nitrogen. The yield of wheat increased for 20t/ha fly ash while paddy and mustard were observed to survive well in soil amended with 10t/ha of fly ash, all three crop plants showed improved growth over control (Kalra et al., 2003). The availability of B in fly ash to alfalfa was shown by Plank and Martens (1974) to be essentially equal to that of sodium borate-B. Application of 5-20\% fly ash on w/w basis in the plough layer (0-15 $\mathrm{cm}$ ) increased both grain and straw yield of pearlmillet (Sorghum vulgare) followed by wheat (Grewal et al., 2001).

Nilesh et al., (2012) reported that the application of fly ash enhances the seed germination rate considerably, whereas in the absence of fly ash (control) rate of seed germination was very slow. The use of fly ash as an admixture in agriculture up to $60 \%$ for the wheat (Triticum aestivum), 10-20\% for mung bean (Vigna radiata), and $20 \%$ for urad beans (Vigna mungo) is suitable for maximum growth and yield. $\mathrm{Cd}, \mathrm{Cu}, \mathrm{Fe}, \mathrm{Mn}, \mathrm{Mg} \mathrm{Ni}, \mathrm{Pb}$, and $\mathrm{Zn}$ were accumulated in the plants under study, but at very low concentrations and below the permissible limits pro-vided for human consumption. Alkaline fly ash with $\mathrm{pH}$ higher than 8 from Illinois has been reported to be beneficial for growth of turfgrass (Cynodon dactylon) and (Lycopersicon esculentum) at $12.5 \%$ with the nutrient content within permissible limits in soil and plants (Chou et al., 2005). Yeledhalli et al., (2008) reported that ash application @ 30-40 t/ha (one time and repeat application) with recommended dose of NPK fertilizers alone or along with FYM @ 20 t/ha was used and the total yield of $35.7 \mathrm{q} / \mathrm{ha}$ was recorded in treatment receiving pond ash @ 40 t/ha along 
with FYM @ 20 t/ha followed by fly ash @ $30 \mathrm{t} / \mathrm{ha}$.

Aggarwal et al., (2009), worked on utilization of fly ash for crop production and effect on the growth of wheat and sorghum crops and soil properties. Soils from both experimental sites and fly ash used in the study were analysed for their physical and chemical characteristics. Surface soil samples (0-30 $\mathrm{cm}$ ) of each location were collected, analysed and averaged for sites' characterization. Wheat cultivar, HD- 2285 was tested for four levels of fly ash, i.e., $0,5,10$ and $20 \mathrm{t} / \mathrm{ha}$ and four levels of $\mathrm{N}$, i.e., $0,25,50$ and $100 \mathrm{~kg} / \mathrm{ha}$ at Muthiani village. Grain and biomass yields increased continuously with combined application of fly ash and nitrogen levels and were 11.8 percent and 14.3 percent higher with $20 \mathrm{t} / \mathrm{ha}$ fly ash and $100 \mathrm{~kg} / \mathrm{ha} \mathrm{N}$ level over control with its values of $2.85 \mathrm{t} / \mathrm{ha}$ and $9.70 \mathrm{t} / \mathrm{ha}$, respectively. Growth characteristics of sorghum were influenced significantly by increasing levels of fly ash and nitrogen. Highest average plant heights of $162 \mathrm{~cm}$ were recorded with $40 \mathrm{~kg} \mathrm{~N}+20 \mathrm{t} / \mathrm{ha}$ fly ash. Test weight of grain was also increased significantly with increasing levels of fly ash. $\mathrm{N}$ and fly ash levels also increased the harvest index of sorghum ranging from 21.6 to 29.0 percent with mean value of 24.95 percent.

Lee et al., (2008) applied fly ash at 0, 40, 80, and $120 \mathrm{Mg} \mathrm{ha}^{-1}$ in paddy soil to determine boron (B) uptake by rice and characteristics of accumulation in the soil. Results indicated that in all fly ash treatments, B content in rice leaves and available B in soil at all growing stages were higher than those of control but all were below toxicity levels. Boron occluded in amorphous iron and aluminium oxides was $20-39 \%$ of total B and was not influenced by fly ash application. Most of the $B$ accumulated by fly ash application was residual $\mathrm{B}$ which is of plant unavailable form and comprised $>60 \%$ of the total $\mathrm{B}$ in soil.
Srivastava and Kumar (2014) carried out to study the effect of different fly ash amendment levels on growth of green manure crop Sesbania cannabina (Dhaincha). Fly ash used in present study was obtained from IFFCO (Indian Farmers fertilizers Cooperative Limited), Phulpur. Fly ash was mixed with garden soil of Botany Department of University of Allahabad, in four different concentrations of fly ash i.e. $0 \%$ (control/garden soil), 25\%, 50\%, 75\% and $100 \%$. A portion of the soil-fly ash mixtures was separated for physio-chemical properties. Pre-soaked seeds of Sesbania cannabina were sown in their respective pots. Data for germination and survival percentages were taken after 15 and 30 days of sowing, respectively. Data for morphological parameters were taken after 45 days of sowing. Some morphological data were taken after maturity of plants. The control set of garden soil and $25 \%$ fly ash exhibited $100 \%$ germination and $100 \%$ survival. In case of $50 \%$ fly ash amended soil germination was $100 \%$ while survival was $93.33 \%$. The overall estimation of germination percentages illustrated that it was not much affected by fly ash amendment while survival was greatly affected in case of $100 \%$ fly ash. The plants sown in $100 \%$ fly ash survived only about 2 months and were with very significantly reduced biomass. The result of present study indicates that the four different amendments tested the amendment level up to $75 \%$, showed no adverse effect on Sesbania pea plant growth and this plant could be used in reclamation of fly ash deposited sites.

Srivastava et al., (2016) reported that fly ash acts as an excellent soil modifier, conditioner and a source of essential nutrients for appreciably improving the texture and fertility with significant increase in crop yield over the control at a particular concentration only and is supportive to plant growth. Moreover, Sahu et al., (2017) also concluded that fly-ash has 
great potentiality in agriculture due to its efficacy in modification of soil health and crop performance. The high concentration of elements (K, Na, Zn, Ca, Mg and $\mathrm{Fe}$ ) in flyash increases the yield of many agricultural crops. But the use of fly-ash in agriculture is limited compare to other sector.

The beneficial effect of fly ash on improvement of soil health in respect of physico-chemical parameters, nutritional status and thereby increasing plant productivity may be due to the cumulative effect of improvement in individual physicochemical characteristics. Further, utilization of fly ash in agriculture may provide a feasible alternative for its safe disposal without serious deleterious effects. However, FA varied widely in its physical and chemical composition, therefore, the mode of use in agriculture is different and depends on the characteristics of soil or soil type. An ultimate goal would be to utilize fly ash in soils to such an extent so as to achieve enhanced fertility and increased crop productivity. Further, there is need to investigate the fate of trace/heavy metals in soil-water-plant system with fly ash applications.

\section{References}

Adriano, D. C., Page, A. L., Elseewi, A. A., Chang, A. C. and Straughan, I. 1980. Utilization and disposal of fly ash and other coal residues in terrestrial ecosystems: A review. J. Environ. Qual. 9: 333-344.

Adriano, D. C., Woodford, T. A. and Criavola, T. G. 1978. Growth and elemental composition of corn and bean seedlings as influenced by soil application of coal ash. J. Environ. Qual. 7: 416-421.

Aggarwal, S., Singh, G. R. and Yadav, B. R. 2009. Utilization of fly ash for crop production: Effect on the growth of wheat and sorghum crops and soil properties. Journal of Agri. Phys. 9: 2023, Web Site: http://www.agrophysics.in.

Aitken, R. L., Campbell, D. J. and Bell, L. C. 1984. Properties of Australian fly ash relevant to their agronomic utilization. Aust. J. Soil Res. 22: 443-453.

Anonymous, 2003. Fly ash facts for Highway Engineers. Techinal Report Documentation (FHWA-IF-03-019), American Coal Association.

Bhattacharya, S. S. and Chattopadhyay, G. N. 2002. Increased Bioavailability of Phosphorous from Fly Ash through Vermicomposting. J. Environ. Qual. 31: 2116-2119.

Chou, S. F. J., Chou, M. I. M., Joseph, W. S., Warnock, D., Chemler, J. A. and Peppie, M. A. 2005. Plant growth in sandy soil/compost mixture and commercial peat moss both amended with Illinois coal fly ash. http://www.fly ash.info/2003/206 cho.pdf.

Craini, R. C. 1988. Studies on effect of fly ash on the physical and chemical characteristics of a clay soil. M.Sc., Thesis, Gujarat Agricultural University, Ahamedabad, p. 318.

Davison, R. L., Natusch, D. F. S., Wallace, J. R. and Evans, C. A. 1974. Trace elements in fly ash: Dependence of concentration on particle size. Environ. Sci. Technol. 8: 1107-1113.

Deshmukh, A., Matte, D. B., Kene, D. R. and Bhaisare, B. 2000. Soil properties as influenced by fly ash application. J. Soil Crops. 10(1): 69-71.

Fail, J. L. and Wochok, Z. S. 1977. Soyabean growth on fly ash amended strip mine spoils. Plant and Soil. 48: 473-484.

Fischer, G. L., Chang D. P. Y. and Brummer, M. 1976. Fly ash collected from electrostatic precipitator. Microcrystalline structures and the 
mystery of the spheres. Science. 19: 553.

Fly Ash-Wikipedia, 2011. The free encyclopedia En.wikipedia.org/wiki/ Fly_ash-12k.Xiuping Feng, Boyd Clark, Evaluation of the Physical and Chemical Properties of Fly Ash products for use in Portland Cement Concrete, 2011 world of coal Ash (WOCA) Conference held in Denver, Co. USA on May 9-12.

Furr, A. K., Kelly, W. C., Bache, C. A., Guternmann, W. H. and Lisk, D. J. 1979. Multi element uptake by vegetables and millet grown in pots on fly ash amended soil. J. of Agri. Food Chem. 24: 885-888.

Gaind, S. and Gaur, A. C. 2002. Impact of fly ash and phosphate solubilising bacteria on Soybean productivity. Bioresour. Technol. 85: 313-315.

Garg, R. N., Pathak, H., Das, D. K. 2005. Use of fly ash and biogas slurry for improving wheat yield and physical properties of soil. Environ. Monit. Assess. 107: 1-9.

Gourab, R. and Joy, V. C. 2011. Dose-related effect of fly ash on edaphic properties in laterite Cropland soil. Ecot. and Environ. Safe. 74(4): 769-775.

Green, J. B. and Manahan, S. E. 1978. Determination of acid base and solubility behaviour of lignite fly ash by selective dissolution in mineral acids. Anal. Chem. 50: 1975-80.

Grewal, K. S., Yadav, P. S., Mehta, S. C. and Oswal, M. C. 2001. Direct and residual effect of fly ash application to soil on crop yield and soil properties. Crop Res. 21: 60-65.

Hussain, S.1993. Agricultural utility of fly ash M.Sc. (Ag.) thesis, University of Agricultural Sciences, Dharwad.

Jamwal, N. 2003. Is it all grey? Down Earth 2003. 6: 38-41.
Kalra, N., Jain, M. C., Joshi, H. C. Choudhary, R., Kumar, S., Pathak, H., Sharma, S. K., Kumar, V., Kumar, R., Harit, R. C., Khan, S. A., Hussain, M. Z. 2003. Soil properties and crop productivity as influenced by fly ash incorporation in soil. Environ. Monit. Assess. 87(1): 93-109.

Kene, D. R., Lanjewas, S. A., Ingole, B. M. and Chaphale, S. D. 1991. Effect of application of fly ash on physiochemical properties of soil. J. Soils \& Crop. 1(1): 11-18.

Khajanchi, L., Chhabra, R., Mongia, A. D., Meena, R. L. and Yadav, R. K. 2012. Release and Uptake of Potassium and Sodium with Fly Ash Application in Rice on Reclaimed Alkali Soil. $J$. Indian Soc. Soil Sci. 60(3): 181-186.

Lee, H., Ha, H. S., Lee, C. S., Lee, Y. B., Kim, P. J. 2008. Characteristics of boron accumulation by flyash application in paddy soil. Bioresour Technol. 99(13): 28-32.

Maiti, S. S., Mukhopadhyay, M., Gupta, S. K. and Banerjee, S. K. 1990. Evaluation of fly ash as useful material in Agriculture. J. Indian Soc. Soil Sci. 38: 342-344.

Mattee, D. B. and Thakare, K. K. 1994. Yield oil content and uptake of groundnut grown in vertisol as influenced by fly ash. National seminar on development in soil science (Extended summaries, part-II). Diamond Jubilee of ISSS. November $28^{\text {th }}$ to December 1 st held at IARI, New Delhi, p.732-734.

Mattigod, S. V., Rai, D., Eary, L. E. and Ainsworth C. C. 1990. Geochemical factors controlling the mobilization of inorganic constituents from fossil fuel combustion residues: A Review of the major elements. J. Environ. Qual. 19: 188-201.

Mishra, L. C. and Shukla, K. N. 1986. Effect of fly ash deposition on growth, metabolism and dry matter production 
of maize and soybean. J. Environ. Pollu. 42(1): 1-13.

Murugan, S. and Murugaiyan, V. 2013. Effect of Fly Ash in Agricultural Field on Soil Properties and Crop Productivity- A Review. Inter. J. Eng. Res. and Tech. 2(12): 54-60.

Nilesh, K. M., Sachin, D. P., Dhananjay, B. S. and Sanjay, B. A. 2012. Effect of Fly Ash as an Admixture in Agriculture and the Study of Heavy Metal Accumulation in Wheat (Triticum aestivum), Mung Bean (Vigna radiata), and Urad Beans (Vigna mungo). Pol. J. Environ. Stud. 21(6): 1713-1719.

Nyambura, M. G., Mugera, W. G., Felicia, P. L. and Gathura, N. P. 2011. Carbonation of brine impacted fractional coal fly ash: implications for C02 sequestration. J. Environ. Manage. 92: 655-664.

Page, A. L., Elseewi, A. A. and Straughan I. R. 1979. Physical and Chemical properties of fly ash from coal-fired power plants with special reference to environmental impacts. Residue Rev. 71: 83-120.

Pandey, V. C. and Singh, N. 2010. Impact of fly ash incorporation in soil systems. Agri. Ecosys. \& Environ. 136: 16-27.

Pandian, N. S., Rajasekhar, C. and Sridharan, A. 1998. Studies of the specific gravity of some Indian coal ashes. J. Test. Eval. 26(3): 177-186.

Plank, C. O. and Martens D. C. 1974. Boron availability as influenced by application of fly ash to soil. Soil Sci. Soc. Am. Proc. 38: 974-977.

Rao, A. V. and Tak, R. 2001. Growth of different tree species and their nutrient uptake in limestone mine spoil as influenced by Arbuscular mycorrhizal (AM)-fungi in Indian arid zone. J. Arid Environ. 113-119.

Reddy, T., Prabhakar, U., Rao, M. and Chandrasekhar, R. 2010. Effect of fly ash and farm yard manure on soil properties and yield of rice grown on an Inceptisol. Agricultural Sci. Dig. 30: 281-285.

Rethman, N. F. G. and Truter, W. F. 2001. Plant responses on soils ameliorated with waste products. $16^{\text {th }}$ National Meeting of ASSMR, Albuquerque, New Mexico, U.S.A., pp. 425.

Reynolds, K. A., Kruger, R. A. and Rethman, N. F. G. 1999. The manufacture and evaluation of an artificial soil prepared from fly ash and sewage sludge. Proc. Intl. Ash Utiliz. Sympos. Lexington, Kentucky, U.S.A., pp. 378-385.

Rungsun, I. E., Bamroongrugsa, N., Kawashima, K., Amano, T. and Kato, S. 2004. Utilisation of coal ash to improve acid soil. J. Sci. Technol. 26: 697-708.

Sahu, G., Bag, A. G., Chatterjee, N. and Mukherjee, A. K. 2017. Potential use of flyash in agriculture: A way to improve soil health. J. Pharma. \& Phytochem. 6(6): 873-880.

Saini, S. P., Manchanda, J. S., Kansal, B. D. and Arora, C. L. 2010. Effect of fly ash and FYM application on yield and macro and micronutrients availability to rice. Environ. Eco. 28(2): 923-929.

Schutter, M. E. and Fuhrmann, J. J. 2001. Soil microbial community responses to fly ash amendment as revealed by analyses of whole soils and bacterial isolates. Soil Biol. Biochem. 33: 1947-1958.

Selvakumari, G., Baskar, M., Jayanthi, D. and Mathan, K. K. 2000. Effect of integration of fly ash with fertilizers and organic manure on nutrient availability, yield and nutrient uptake of rice in Alfisols. J. Indian Soc. Soil Sci. 48: 268-278.

Sharma, S. K., Kalra, Naveen and Singh, G. R. 2002. Soil physical and chemical properties as influenced by fly ash addition in soil and yield of wheat. $J$. Sci. Indus. Res. 61:617-620. 
Shenggao, L. and Lei, Z. 2004. Effect of fly ash on physical properties of ultisols from subtropical China. Commun. Soils and Plant Anal.35 (4@5): 703-717.

Singh, J. S., Pandey, V. C. and Singh, D. P. 2011. Coal fly ash and farmyard manure amendments in dry-land paddy agriculture field: effect on $\mathrm{N}$-dynamics and paddy productivity. Applied SoilEco. 47 (2): 133-140.

Singh, N. B. and Singh, M. 1986. Influence of fly ash on NPK contents and their uptake by rice grown in saline soil at different fertility level. Oryza. 23: 145151.

Singh, S. N., Kulshreshtha, K. and Ahmad, K. J. 1997. Impact of fly ash soil amendment on seed germination, seedling growth and metal composition of Vicia faba L. Ecol. Engg. 9: 203-208.

Srivastava, N. and Kumar, G. 2014. An Ecofriendly method for reducing the risk of fly ash using Sesbania cannabina
(Dhaincha). Res. J. Recent Sci. 4(3): 6367.

Srivastava, R. K., Srivastava, A. K. and Gautam, P. 2016. Eco-friendly utilization of fly ash in agriculture: A review. Inter. J. Environ. \& Pollution Res. 4(4): 24-33.

West, T. O. and McBride, A. C. 2005. The contribution of agricultural lime to carbon dioxide emissions in the United States: dissolution, transport, and net emissions. Agric. Ecosys. Environ. 108(2): 145-154.

Yeledhalli, N. A, Prakash, S. S, Ravi, M. V. and Narayana, R. 2008. Long-Term Effect of Fly Ash on Crop Yield and Soil Properties. Karnataka J. Agric. Sci. 21(4): 507-512.

Zhang, G. Y., Dou, Z., Toth, J. D. and Ferguson, J. 2004. Use of fly ash as environmental and agronomic amendments. Environ. Geochem. Health. 26: 129-134.

\section{How to cite this article:}

Harender Singh Dahiya and Yogendra Kumar Budania. 2018. Prospects of Fly Ash Application in Agriculture: A Global Review. Int.J.Curr.Microbiol.App.Sci. 7(10): 397-409. doi: https://doi.org/10.20546/ijcmas.2018.710.043 